\title{
Testosterone metabolites inhibit proliferation of castration- and therapy-resistant prostate cancer
}

\author{
Felix Bremmer ${ }^{1}$, Hubertus Jarry², Valerie Unterkircher ${ }^{1}$, Silke Kaulfuss ${ }^{3}$, Peter \\ Burfeind ${ }^{3}$, Heinz-Joachim Radzun ${ }^{4}$, Philipp Ströbel ${ }^{4}$ and Paul Thelen ${ }^{5}$ \\ ${ }^{1}$ Institute of Pathology, University Medical Center, Göttingen 37075, Germany \\ ${ }^{2}$ Department of Experimental Endocrinology, University Medical Center, Göttingen 37075, Germany \\ ${ }^{3}$ Institute of Human Genetics, University Medical Center, Göttingen 37073, Germany \\ ${ }^{4}$ Institute of Pathology, University Medical Center, Göttingen 37075, Germany \\ ${ }^{5}$ Department of Urology, University Medical Center, Göttingen 37075, Germany \\ Correspondence to: Felix Bremmer, email: felix.bremmer@med.uni-goettingen.de \\ Keywords: castration resistant prostate cancer; AKRIC1; AKRIC2 and AKRIC3; 3a-androstendiol; 3b-androstendiol \\ Received: December 07, $2017 \quad$ Accepted: February 27, $2018 \quad$ Published: March 30, 2018 \\ Copyright: Bremmer et al. This is an open-access article distributed under the terms of the Creative Commons Attribution License \\ 3.0 (CC BY 3.0), which permits unrestricted use, distribution, and reproduction in any medium, provided the original author and \\ source are credited.
}

\section{ABSTRACT}

Novel treatments for castration-resistant prostate cancer (CRPC) such as abiraterone acetate (AA) or enzalutamide effectively target the androgen pathway to arrest aberrant signalling and cell proliferation. Testosterone is able to inhibit tumour cell growth in CRPC. Estrogen receptor-beta (ERß) binds the testosterone-

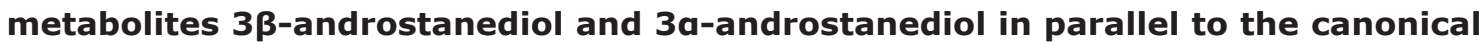
estradiol. In the prostate it is widely accepted that ER $\beta$ regulates estrogen signalling, mediating anti-proliferative effects. We used the prostate cancer cell lines LNCaP, PC-3, VCaP, and the non-neoplastic BPH-1. VCaP cells were treated with $1 \mathrm{nmol} / \mathrm{L}$ testosterone over 20 passages, yielding the cell line VCaPrev, sensitive to hormone therapies. In contrast, LNCaP cells were grown for more than 100 passages yielding a high passage therapy resistant cell line $\left(_{\text {hip }}\right.$ LNCaP). VCaP and ${ }_{\text {hip }}$ LNCaP cell lines were treated with $5 \mu \mathrm{mol} / \mathrm{L}$ AA for more than 20 passages, respectively, generating the AAtolerant-subtypes VCaPAA and hiPLNCaPAA. Cell lines were treated with testosterone, dihydrotestosterone (DHT), R1881, and the androgen-metabolites $3 \beta$-androstanediol

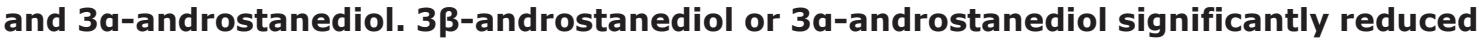
proliferation in all cell lines except the BPH-1 and androgen receptor-negative PC-3 and markedly downregulated $A R$ and estrogen receptor alpha (ERa). Whereas ER $\beta$ expression was increased in all cell lines except BPH-1 or PC-3. In summary, $3 \beta$-adiol or 3a-adiol, as well as DHT and $\mathbf{R 1 8 8 1}$, significantly reduced tumour cell growth in CRPC cells. Thus, these compounds represent novel potential therapeutic approaches to overcome drug-resistance in CRPC, especially with regard to AR-V7 function in therapy resistance. Furthermore, these data confirm the tumour suppressor properties of ERB in CRPC.

\section{INTRODUCTION}

Prostate cancer $(\mathrm{PCa})$ is the most prevalent cancer among men in Europe. Its incidence has increased continuously over the past decades $[1,2]$. In some cases, localised PCa can be cured by radical prostatectomy, radiotherapy, and/or androgen deprivation therapy [3]. However, castration-resistant $\mathrm{PCa}$ (CRPC) remains incurable, even after the development of highly active agents such as abiraterone (an inhibitor of steroidogenesis) or enzalutamide (a second-generation androgen receptor antagonist). Eventually, approximately $20-40 \%$ of patients 
do not respond to these agents, based on prostate-specific antigen (PSA) -response (i.e. primary resistance) [4-7]. Thus CRPC depends on AR-signalling for progression [8].

In addition to such compounds that prevent androgen synthesis (i.e. abiraterone) or androgen receptor antagonists (i.e. Enzalutamid or Bicalutamid) [9], derivatives of androgen biosynthesis such as testosterone or $5 \alpha$-dihydrotestosterone ( $5 \alpha-\mathrm{DHT})$ effectively reduce tumour growth in castration resistant VCaP cells [10]. Several observations have demonstrated the significance of intratumoural androgen synthesis after chemical or surgical castration. Genes that are essential for steroid hormone synthesis, such as $A K R 1 C 1$, $A K R 1 C 2$, or $A K R 1 C 3$ are upregulated in CRPC. AKR1C1 and AKR1C2 convert 5a-DHT to $3 \alpha$-androstanediol

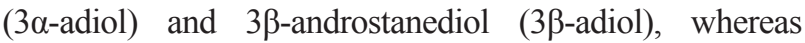
AKRC1C3 converts $\Delta^{4}$-androstenedione to testosterone (Supplementary Figure 1) [9, 11].

Both testosterone-derivatives ( $3 \alpha$-adiol and $3 \beta$-adiol) have significant affinity for estrogen receptor alpha (ERa) and beta $(\mathrm{ER} \beta)[12,13]$. ERa is predominantly expressed in the prostate stroma and thus has a paracrine effect, whereas ER $\beta$ is expressed in the prostate epithelium and is decreased in PCa. ER $\beta$ protects against aberrant cell proliferation and carcinogenesis and thus is termed a tumour suppressor [14-18].

Another driver of CRPC is the overexpression of the androgen receptor (AR). Overexpression of AR compensates for reduced androgen levels, augmenting continuous tumour growth. This leads to a significant increase in AR-mediated gene transcription, including upregulation of TMPSSR-ERG, IGF1, and PSA, [9, 10]. Further molecular mechanisms include AR-splice variants such as ARV7, which constitutively activate AR [17-19]. Antonarakis et al. (2014) demonstrated an association between ARV7 and resistance to both enzalutamide and abiraterone in CRPC [20].

The abilities to overcome such therapy resistance by androgen metabolites such as $3 \alpha$-adiol and $3 \beta$-adiol, in CRPC, have not been considered so far. Recently, we demonstrated the ability of the ER-subtype selective compound $8 \beta \mathrm{VE}-2$ to reset resistance to hormone therapies [21]. In this study, we investigated the effect of $3 \alpha$-adiol, and $3 \beta$-adiol on various $\mathrm{PCa}$ cells with regard to gain of function AR-aberrations and alternative gene splicing exemplified by AR-splice variant 7 (AR-V7).

\section{RESULTS}

\section{Reduced proliferation of AR-positive PCa cells after treatment with $3 \alpha$-diol}

After $48 \mathrm{~h}$ treatment with $5 \mathrm{nmol} / \mathrm{L}$ to $1 \mu \mathrm{mol} / \mathrm{L}$ $3 \alpha$-adiol, proliferation of LNCaP cells, was significantly reduced ( $p<0.0005$, Figure 1A), despite the gain-offunction AR mutation T878A, vastly defying hormone therapies. Such inhibition of proliferation with $3 \alpha$-adiol treatments was not observed in AR-negative PC-3 or non-malignant BPH-1 cells (Figure 1B, 1C). In contrast, androgen-sensitive $\mathrm{VCaPrev}$ cancer cells represent a preandrogen deprivation (preADT) therapy stage (Figure 1D). These cells also showed a significant reduction in proliferation with $5 \mathrm{nmol} / \mathrm{L}(p<0.05)$ and $10 \mathrm{nmol} / \mathrm{L}$ to $1 \mu \mathrm{mol} / \mathrm{L}(p<0.005) 3 \alpha$-adiol; however, the effect was less prominent as compared with $\mathrm{VCaP}$ cells representing established CRPC and VCaP AA cells (Figure 1E, 1F). In addition, a significant reduction in proliferation was observed in the high passage cell line ${ }_{\text {hiP }} \mathrm{LNCaP}$, albeit only with higher concentrations of $5 \mathrm{nmol} / \mathrm{L}$ to $1 \mu \mathrm{mol} / \mathrm{L}$ $(p<0.005)$, (Figure $1 \mathrm{G}$ ) but basically unaltered from the original LNCaP (Figure 1A). In the same range of concentrations, $3 \alpha$-adiol still significantly reduced proliferation in the therapy-resistant cell model ${ }_{\text {hip }} \mathrm{LNCaP}^{\mathrm{AA}}$ (Figure 1H).

\section{Proliferation of prostate cells after treatment with $3 \beta$-adiol for comparison}

Effects on tumour cell proliferation of various CRPC models observed with $3 \alpha$-adiol were also observed with $3 \beta$-adiol (Figure 2 ). In almost congruent concentration ranges the $3 \beta$-isoform of adiol also elicited decreased proliferation of PCa-cells with AR-aberrations but not in AR-negative PC-3 tumour cells (Figure 2B) and non-neoplastic AR-positive BPH-1 cells (Figure 2C). Not as effective as $3 \alpha$-adiol in very low concentrations, $3 \beta$-adiol also shows the striking difference of adiol therapy potential between permanent CRPC, based on AR-gain-offunction models (LNCaP, Figure 2A, 2G, 2H) and CRPC, based on AR-deregulation and alternative AR-splicing (VCaP, Figure 2D-2F). Gain-of-function-AR LNCaP show decreased proliferation upon adiol treatments only above $1 \mathrm{nM}$ concentrations (Figures $1 \mathrm{~A}, 1 \mathrm{G}$ and $1 \mathrm{H}$, $2 \mathrm{G}-2 \mathrm{H})$. A lower therapy potential is also obvious in $\mathrm{VCaP}$ cells before androgen deprivation, i.e. in the presence of $1 \mathrm{nM}$ external testosterone (Figures 1D, 2D). However, with increasing ADT, first deprivation of external androgen (Figures 1E, 2E) and AA-treatment in addition (Figures 1F, 2F), there is an obvious potential to overcome CRPC from adiol treatments. For the therapy resistance mechanisms from ADT lowest adiol concentrations are sufficient to reduce tumour cell proliferation significantly with a slight advantage for $3 \alpha$-adiol (Figure 1E-1F, Figure 2E-2F). In contrast, LNCaP-derived CRPC models with already permanent AR-mutations largely remain unaltered in their susceptibility to adiol treatments with increasing passage numbers (Figures 1 and 2; A compared with G) and AA-treatments (Figures 1 and 2; G compared with $\mathrm{H}$ ). 


\section{$3 \alpha$-adiol or $3 \beta$-adiol arrest cell cycle in PCa cell lines}

The effect of both adiols on PCa proliferation caused us to investigate cell cycle events. PCa cell lines were treated with $1 \mu \mathrm{mol} / \mathrm{L} 3 \alpha$-adiol or $1 \mu \mathrm{mol} / \mathrm{L}$ $3 \beta$-adiol, or androgen stimulated with $10 \mathrm{nmol} / \mathrm{L} \mathrm{R} 1881$ (Figure 3). Decreased tumour cell proliferation upon adiol treatments coincide with cells arrested in G0/G1 phase and less continuation to $\mathrm{S}-$ and $\mathrm{G} 2 / \mathrm{M}$ phase. In comparison, androgen stimulation with R1881 does not show these effects on CRPC cell cycle in VCaP cells (data not shown). These cell cycle events are most pronounced for CRPC cells (Figure 3A-3C) and are still obvious after AA treatments (Figure 3D-3F), albeit untreated pre-ADT cells do not reveal cell cycle alterations from adiols or androgen R1881 (data not shown). In contrast G0/G1 arrest from the adiols but not from R1881 is obvious in all LNCaP cells (Figure 3G-3I) and its derivatives (data not shown).
This obvious growth constraint and cell cycle arrest induced in prostate cancer by adiols caused us to confirm the functional expression of the enzymes they originate from, especially AKR1C1 and AKR1C2. AKR1C1, AKR1C2 as well AKR1C3 are expressed in the presence of substrate androgens $(\mathrm{VCaP}$ rev and $\mathrm{LNCaP}$ with testosterone or DHT supplementation). AKR1C1 is slightly downregulated in the presence of its product $3 \beta$-adiol but no such effects became obvious for AKR1C2 and $3 \alpha$-adiol (Supplementary Figure 2).

\section{Influence from adiol treatments on AR-, ERa-, and ERß-expression}

Since therapy resistance of CRPC is predominantly affected by AR characteristics (overexpression, gain-offunction mutations), we investigated AR expression in these different cell models and compared adiol treatments to androgen stimulation with non-metabolizable androgen

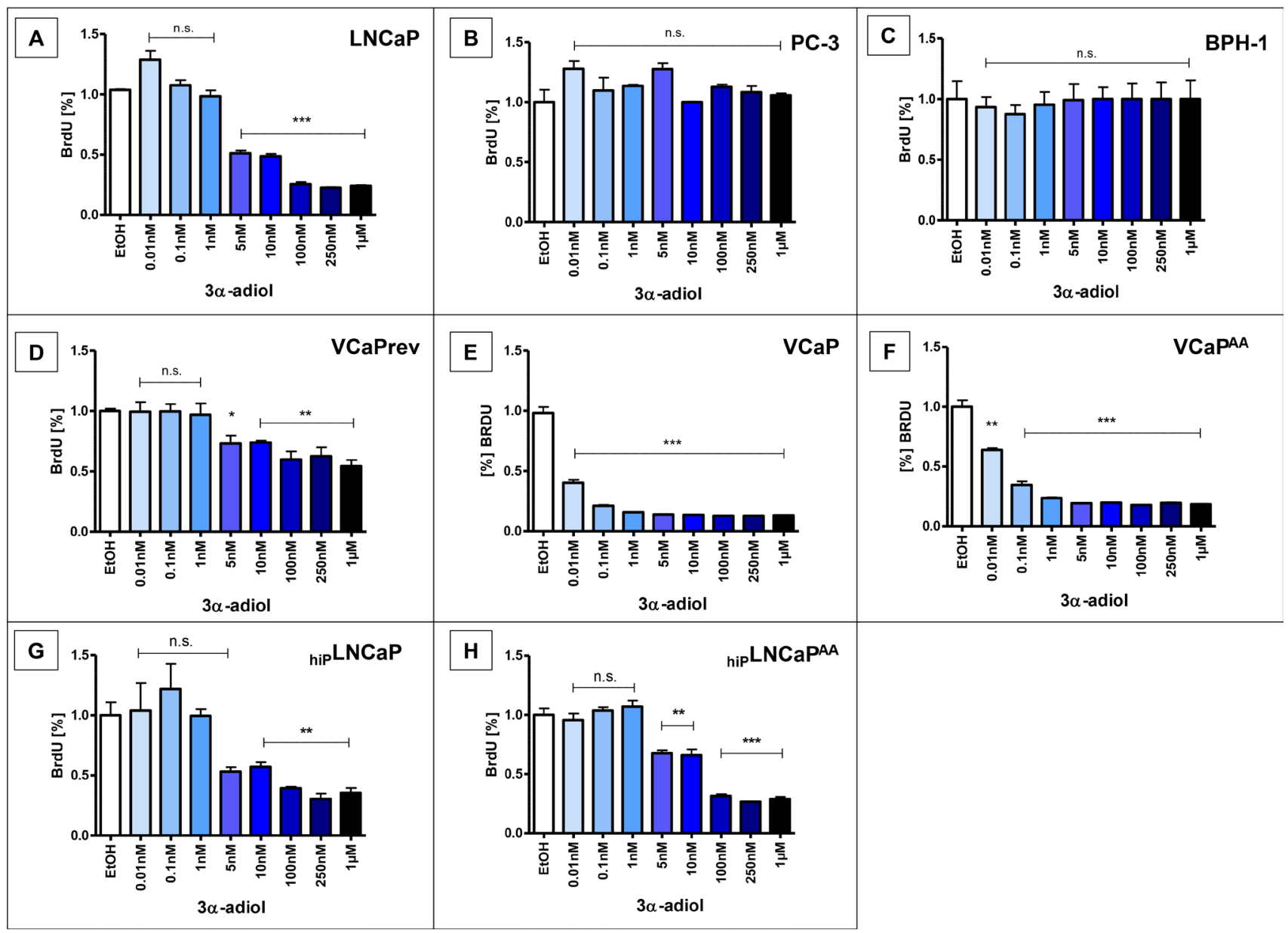

Figure 1: Proliferation after treatment with $\mathbf{3 \alpha}$-adiol. Several prostate cancer cell lines were treated with $0,0.01,0.1,1,5,10$, 100,250 , or $1000 \mathrm{nmol} / \mathrm{L} 3 \alpha$-adiol. Proliferation was assessed by performing BrdU-ELISA. $3 \alpha$-adiol led to a significant reduction in proliferation in various $\mathrm{LNCaP}$ - and $\mathrm{VCaP}$-derived cell lines, whereas androgen receptor (AR)-negative PC-3 and non-neoplastic BPH-1 cells showed no changes in proliferation (n.s. $=$ not significant, ${ }^{*} P<0.05,{ }^{* *} P<0.005,{ }^{* * *} P<0.0005$ ). 
R1881. Furthermore, we evaluated estrogen receptors (ER $\alpha$ and $E R \beta)$ as potential target for these compounds. PCa cell lines were treated with adiol concentrations of $1 \mu \mathrm{mol} / \mathrm{L}$, an effective dosis in previous experiments, or $10 \mathrm{nmol} / \mathrm{L} \mathrm{R} 1881$, which is comparable to physiological androgen concentrations. After treatment, western blotting was performed to investigate the expression of AR, ER $\alpha$, and $\operatorname{ER} \beta$.

\section{VCaPrev, VCaP, and VCaPA cells (Figure 4A-4C)}

Pre-therapy androgen-sensitive VCaPrev moderately express AR in the presence of sufficient, but subphysiological ( $1 \mathrm{nM}, 0.3 \mathrm{ng} / \mathrm{ml}$ ) testosterone. But also from this low expression level, $3 \alpha$-adiol or $3 \beta$-adiol treatments led to a considerable reduction in AR expression, whereas the androgen R1881 increased AR expression. No such divergent effects from adiols and R1881 were observed on $\mathrm{ER} \alpha$ and ER $\beta$ expression (Figure 4A). VCaP cells with no external testosterone in the cell culture represent castration resistant growth (Figure 4B). Under this CRPC condition the AR is slightly up-regulated as compared with the preADT state (Figure 4A). In contrast to AR the estrogen receptors are down-regulated under CRPC condition and they are further down-regulated by adiol-treatments but up-regulated parallel to AR by a stimulatory treatment with R1881 (Figure 4B). The therapy-resistant VCaP derivative $\mathrm{VCaP}^{\mathrm{AA}}$ cells showed the highest expression of AR. With increasing androgen deprivation, AR expression increased to levels significantly above those of VCaPrev and $\mathrm{VCaP}$ cells. However, treatment with $3 \alpha$-adiol or $3 \beta$-adiol markedly reduced AR expression, whereas $\mathrm{R} 1881$ resulted in only a slight increase in AR expression. In addition, $3 \alpha$-adiol or $3 \beta$-adiol also resulted in a considerable reduction in ER $\alpha$ expression. Interestingly, treatment with R1881 resulted in a dramatic increase in ER $\alpha$. Finally, treatment with $3 \alpha$-adiol, $3 \beta$-adiol, or R1881 markedly increased ER $\beta$ expression (Figure 4C).

\section{LNCaP, ${ }_{\text {hiP }} \mathrm{LNCaP}$, and ${ }_{\text {hip }} \mathrm{LNCaP}^{\mathrm{AA}}$ cells (Figure 4D-4F)}

LNCaP cells per se represent the T878A gainof-function mutation and less susceptibility to ADT. To obtain cell models with increased potential for therapy resistance before this background, we established a high-

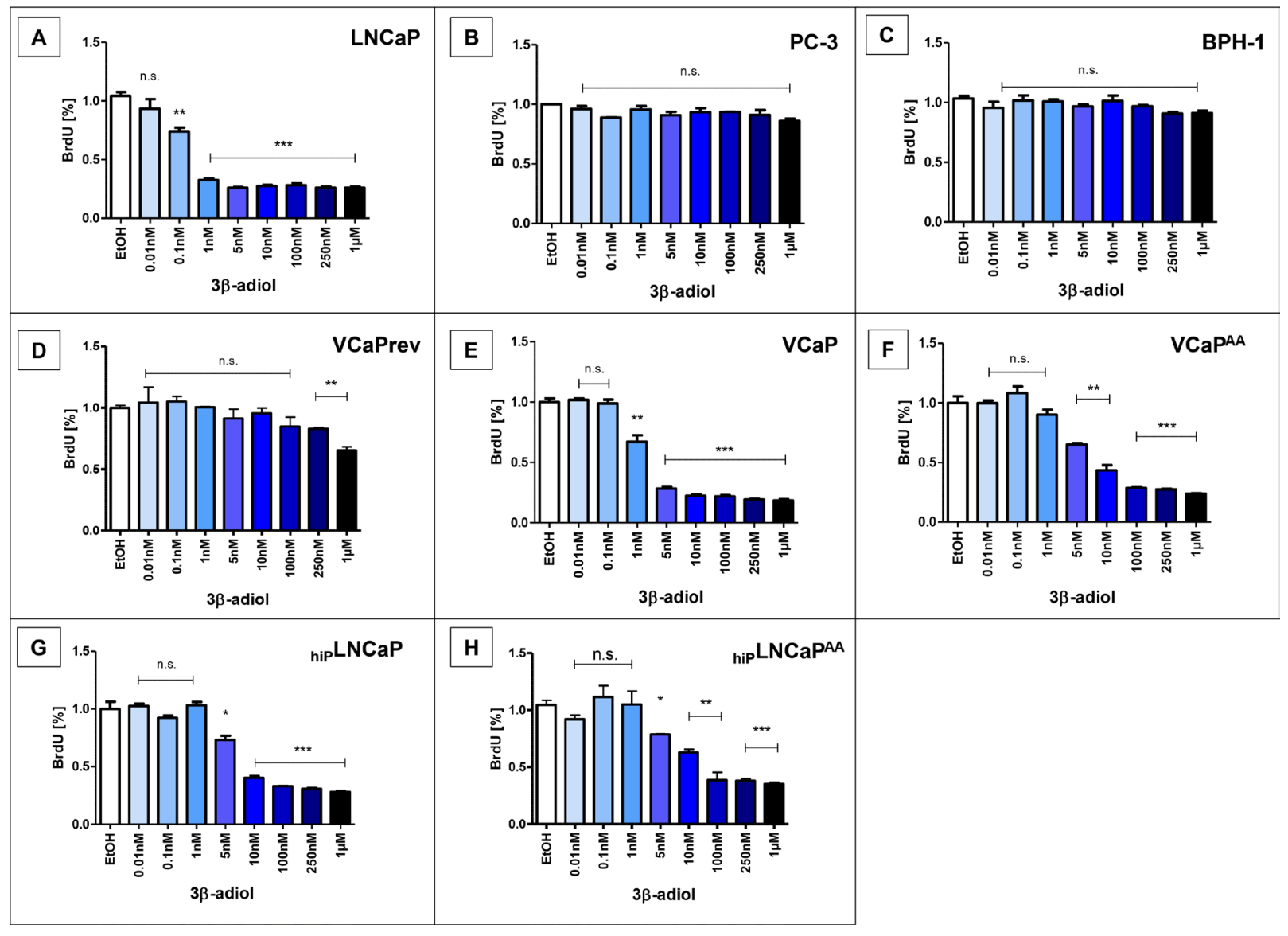

Figure 2: Proliferation after application of $\mathbf{3 \beta}$-adiol. Several prostate cancer cell lines were treated with $0,0.01,0.1,1,5,10,100$, 250 , or $1 \mathrm{nmol} / \mathrm{L} 3 \alpha$-adiol. Proliferation was assessed by performing BrdU-ELISA. $3 \beta$-adiol led to a significant reduction in proliferation in LNCaP and VCaP derivatives, whereas PC-3 and BPH-1 showed no changes in proliferation (n.s. = not significant, ${ }^{*} P<0.05,{ }^{* *} P<0.005$, $\left.{ }^{* * *} P<0.0005\right)$. 
passage $\mathrm{LNCaP}\left({ }_{\text {hiP }} \mathrm{LNCaP}\right)$ and AA-tolerant derivatives $\left({ }_{\text {hip }} \mathrm{LNCaP}^{\mathrm{AA}}\right)$.

There was also considerable expression of the steroid receptors $\mathrm{AR}, \mathrm{ER} \alpha$, and $\mathrm{ER} \beta$ in $\mathrm{LNCaP} \mathrm{CRPC}$ cells. In the $\mathrm{VCaP}$ model, increasing resistance to androgen deprivation was evident by accumulating $\mathrm{AR}$ overexpression (Figure 4A-4C); however, there was no such development in the LNCaP model with the gain-of-function mutation T878A (Figure 4D-4F). Accordingly, treatment with $3 \alpha$-adiol, $3 \beta$-adiol, or R1881 had no significant effect on AR expression in basal LNCaP cells. However, ER $\alpha$ expression was reduced after treatment with $3 \alpha$-adiol or R1881, and markedly reduced with $3 \beta$-adiol. Interestingly, up-regulation was observed for ER $\beta$ upon $3 \alpha$-adiol-, $3 \beta$-adiol-, or R1881treatments (Figure 4D). Moreover, the therapy resistant derivatives from LNCaP, established by prolonged growth under androgen deprivation (Figure 4E) and AAtreatment (Figure 4F) illustrate decisively an ER $\beta$ acting as a counterbalance on AR- and ER $\alpha$-expression. This antiandrogen action from ER $\beta$ was most pronounced after $3 \beta$-adiol-treatments (Figure 4F).

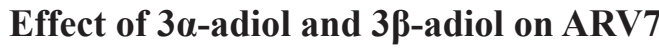 expression}

Recent clinical observations linked therapy resistance and cross resistance to expression of AR splice variants such as AR-V7. Therefore, we analysed the function of AR-V7 in therapy resistance in our cell models (Figure 5). As shown in Figure 4, increasing androgen deprivation and AA-treatment in the $\mathrm{VCaP}$ model resulted in accumulating overexpression of wildtype AR (EtOH-control experiments, Figure 4A-4C). This observation was reproduced in experiments with focus on AR-V7 with specific antibodies. In contrast to an evolving overexpression of AR full length under ADT, the appearance of AR-V7 is stepwise only after fulfilment of ADT with AA-treatments (Figure 5A). All experiments done with the CRPC model T878A-AR LNCaP showed negative results for AR-V7 or other AR splice-variants with N-terminal AR antibodies or specific AR-V7 antibodies (data not shown). As demonstrated in our experiments, the function of AR-overexpression in therapy resistance was reversible with adiol treatments. The

\section{VCaP}

VCaPAA

LNCaP
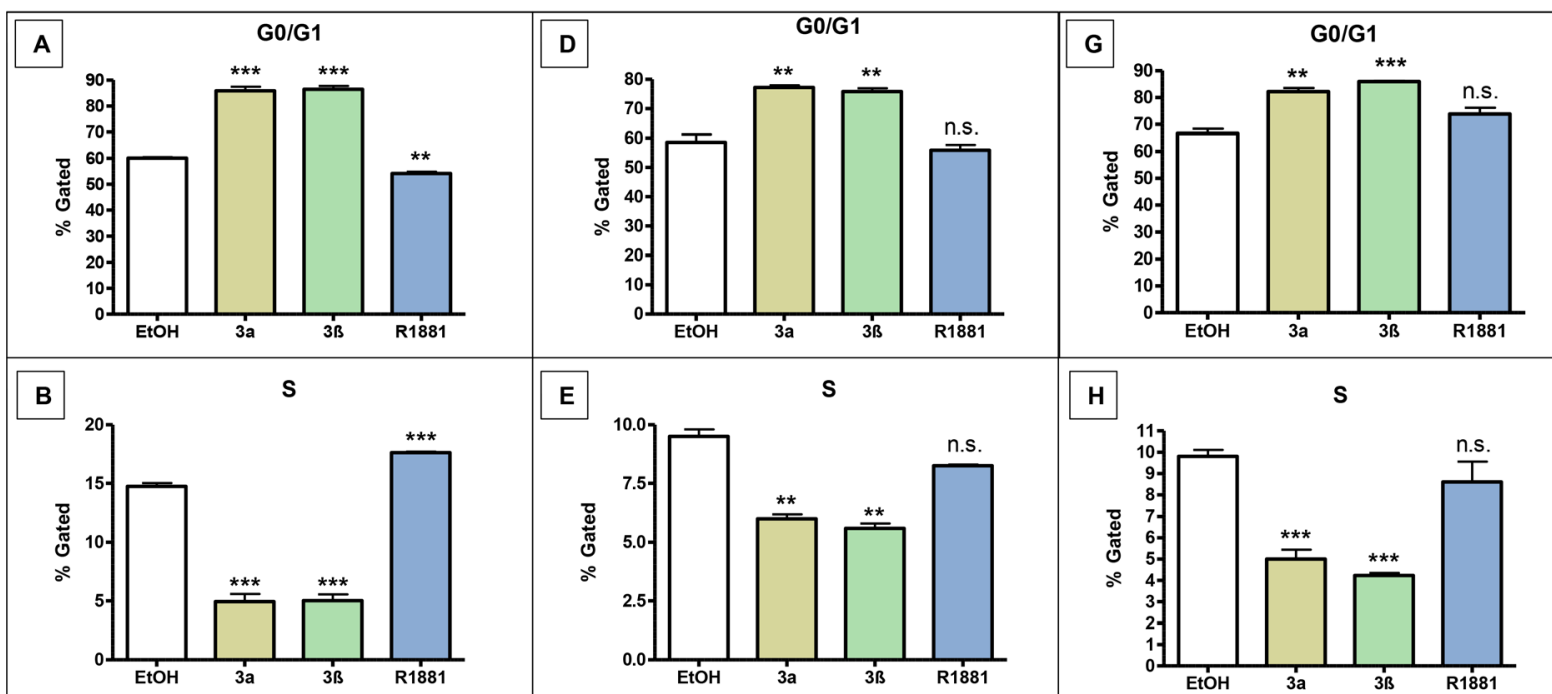

$S$
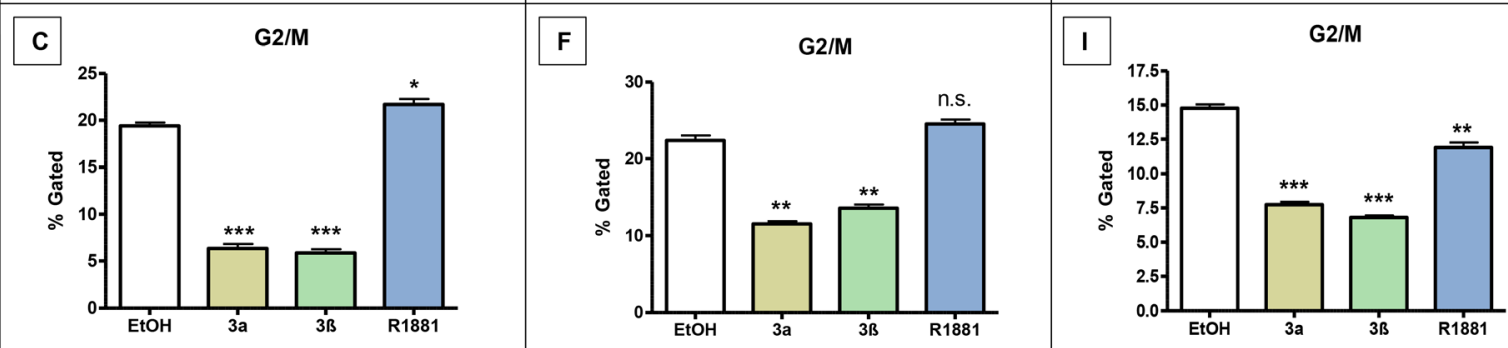

Figure 3: Cell cycle changes in various CRPC-cells after the application of $3 \alpha$-adiol, $3 \beta$-adiol, and R1881. Prostate cancer cell lines were treated with $1 \mu \mathrm{mol} / \mathrm{L} 3 \alpha$-adiol, $1 \mu \mathrm{mol} / \mathrm{L} 3 \beta$-adiol or $10 \mathrm{nmol} / \mathrm{L} \mathrm{R} 1881$. Cell cycle was assessed using the commercial Muse $^{\mathrm{TM}}$ Cell Cycle assay kit. In VCaP and VCaPAA cells, 3a-, 33-adiol significantly increased cell numbers in the G0/G1 phases, whereas cells in the $\mathrm{S}$ or G2/M phases were significantly reduced. R1881 showed an opposite effect with a reduced number of cells in the $\mathrm{G} 0 /$ G1 phases and increased number of cells in the $\mathrm{S}$ and G2/M phases. In VCapAA cells, no significant changes were detected (A-F). In LNCAP 3a- and 3 $\beta$-adiol application led to increases in cells in the G0/G1 phases, whereas the number of cells in $\mathrm{S}$ and $\mathrm{G} 2 / \mathrm{M}$ phases was significantly reduced. R1881 resulted in inconsistent changes $(\mathbf{G}-\mathbf{I})$ (n.s. $=$ not significant, ${ }^{*} P<0.05,{ }^{* *} P<0.005,{ }^{* * *} P<0.0005$ ). 
appearance of $\mathrm{AR}-\mathrm{V} 7$ in $\mathrm{VCaP}^{\mathrm{AA}}$-cells was also reversible by adiol treatments with a slightly better efficacy from $3 \beta$-adiol (Figure 5B).

\section{DISCUSSION}

Conventional anti-hormonal agents, used for the primary treatment of metastatic $\mathrm{PCa}$, are intended to prevent AR activation and curb tumour cell proliferation. Thus, androgen deprivation with LHRH (or GnRH) agonists and antagonists (LHRHa) reduces testosterone production (primarily in the testes) and the number of AR ligands [9]. The efficacy of these compounds typically decreases due to the development of resistance, which undermines androgen deprivation therapy (ADT). Upon new tumour growth, even though serum testosterone levels mimic castration levels, PCa has reached the stage of castration-resistance [22]. Castration resistance can be achieved by two distinct mechanisms represented by the two cell models used in this study, specifically, VCaP (AR aberration) and LNCaP (gain-of-function). The VCaP model allows for androgen-independent growth via $\mathrm{AR}$ overexpression with low testosterone. Completely androgen independent growth is mediated by constitutive active AR splice variants (Figure 5). The LNCaP model permits growth in the absence of androgen, due to the promiscuous use of substitute androgens such as estradiol or flutamide. Therefore, in case of castration resistance, for metastatic PCa, the prognosis is usually dismal.

New AR targeting therapies have been developed for the treatment of patients with $\mathrm{VCaP}$ based on evidence emphasizing the importance of AR signalling. Therefore, it is generally accepted that AR signalling is a key driver of CRPC [23, 24].

Novel treatments such as AA, which suppresses ligand synthesis, or enzalutamide, which completely

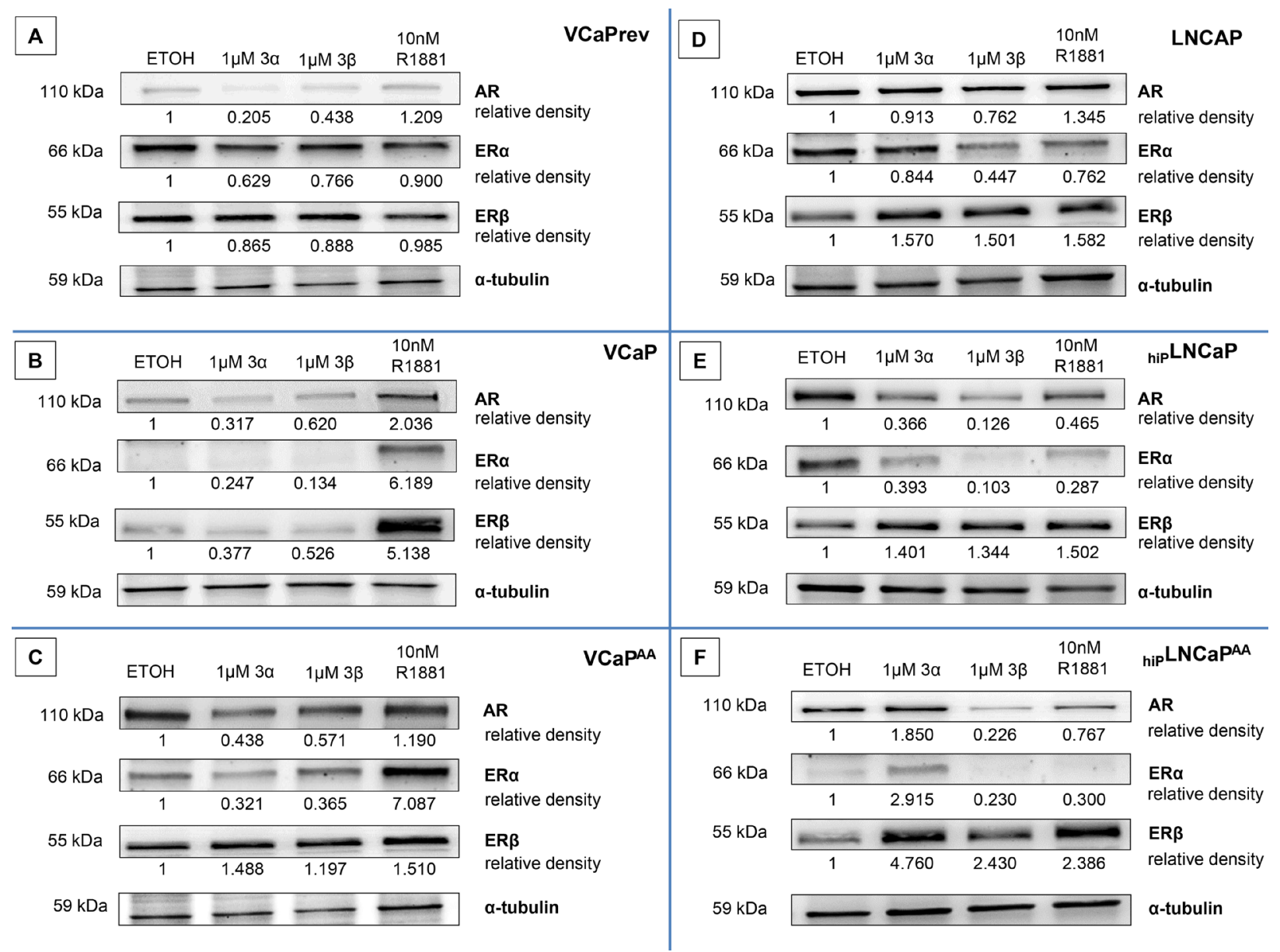

Figure 4: Androgen receptor (AR), Oestrogen receptor (ER)a, and ERß expression after treatment with 3a-adiol, 3ß-adiol, and R1881. Western blotting was performed to determine protein expression. $3 \alpha$-adiol $(1 \mu \mathrm{mol} / \mathrm{L})$ or $3 \beta$-adiol $(1 \mu \mathrm{mol})$ considerably reduced AR expression in VCaPrev cells, whereas $10 \mathrm{nmol} / \mathrm{L}$ R 1881 resulted in a slight induction of AR expression. In addition, no significant changes in ERa or ER $\beta$ expression were detectable (A). In VCaP cells, $1 \mu \mathrm{mol} / \mathrm{L} 3 \alpha$-adiol or $1 \mu \mathrm{mol} / \mathrm{L} 3 \beta$-adiol reduced AR expression, whereas $10 \mathrm{nmol} / \mathrm{L}$ R1881 resulted in elevated AR expression. R1881, but not $3 \alpha$-adiol and $3 \beta$-adiol, stimulated the expression of ERa or ER $\beta$ (B). $3 \alpha$-adiol $(1 \mu \mathrm{mol} / \mathrm{L})$ or $3 \beta$-adiol $(1 \mu \mathrm{mol} / \mathrm{L})$ markedly reduced AR expression in VCaPAA cells, whereas 10 $\mathrm{nmol} / \mathrm{L}$ R1881 resulted in a slight increase in AR expression. $3 \alpha$-adiol $(1 \mu \mathrm{mol} / \mathrm{L})$ or $3 \beta$-adiol $(1 \mu \mathrm{mol} / \mathrm{L})$, as well as androgen stimulation with R1881, reduced ERa expression and increased ER $\beta$ expression (C). The opposite regulation of protein expression (downregulation for ERa and upregulation for ER $\beta$ ) by $1 \mu \mathrm{mol} / \mathrm{L} 3 \alpha$-adiol or $1 \mu \mathrm{mol} / \mathrm{L} 3 \beta$-adiol was even more pronounced for LNCaP derivatives (D-F). 
blocks the AR, effectively target the androgen pathway to arrest aberrant signalling, and are therefore most suitable for CRPC treatment [5-7, 25]. However, both functional agents can fail due to AR splice variants [20]. AR overexpression and AR-V occurrence might be reversible but gain-of-function somatic mutations persist even with drug withdrawal. In this regard, it has become evident that androgens are able to eliminate tumour cell growth in CRPC (Supplementary Figures 3-5) [10]. The concept of bipolar androgen therapy has proven efficient in overcoming therapy resistance due to androgen exposure [26]. Especially in VCaP tumour cells, high levels of testosterone can induce DNA double strand breaks and disrupt the function of AR. This was shown to result in inhibition of proliferation in PCa cells [26].

These findings are similar to the results in our study. We confirmed that low (nmol/L) concentrations of R1881, testosterone, and 5a-DHT effectively reduce proliferation in $\mathrm{LNCaP}, \mathrm{VCaP}, \mathrm{VCaP}{ }^{\mathrm{AA}}$, ${ }_{\text {hiP }} \mathrm{LNCaP}$, and ${ }_{\text {hiP }} \mathrm{LNCaP}^{\mathrm{AA}}$ cells, whereas the original pre-treatment cell model $\mathrm{VCaPrev}$ only showed marginal androgen-stimulated proliferation. Furthermore, it is evident that intratumoural steroidogenesis is crucial in CRPC. In addition, it is known that the androgen biosynthesis enzymes AKR1C1, AKR1C2, and $\mathrm{AKR} 1 \mathrm{C} 3$ are upregulated in prostate cancer [9]. AKR1C1 and AKR1C2 convert 5a-DHT to $3 \alpha$-adiol and $3 \beta$-adiol [11]. However, the expression of AKR1C1, AKR1C2, and AKR1C3 did not significantly differ after treatment with $3 \alpha$-adiol or $3 \beta$-adiol (Supplementary Figure 2).

Notably, we did show that $3 \alpha$-adiol or $3 \beta$-adiol leads to a significantly reduced proliferation in $\mathrm{LNCaP}$, VCaPrev, VCaP, VCaPA, ${ }_{\text {hip }} \mathrm{LNCaP}$, and ${ }_{\text {hip }} \mathrm{LNCaP}^{\mathrm{AA}}$ cells, whereas $3 \alpha$-adiol or $3 \beta$-adiol did not affect BPH-1 and PC-3 cell proliferation. Guerini et al. (2005) demonstrated that $3 \alpha$-adiol and $3 \beta$-adiol reduces tumour cell migration in AR-negative DU145 PCa cells. Inhibition of DU145 cell motility has been associated with the formation of the testosterone/dihydrotestosterone metabolite $3 \beta$-adiol, which acts through the activation of $\mathrm{ER} \beta$, which is present in these PCa cells [27]. In the prostate, ER $\beta$ has features of a tumour suppressor. It is widely accepted that ER $\beta$ adopts a regulatory role in estrogen signalling, mediating anti-proliferative effects. In this study, we investigated the effects of testosterone-metabolites with regard to proliferation and estrogen signalling.

In addition, it has been shown that $3 \alpha$-adiol and $3 \beta$-adiol, two metabolites that do not bind the AR, have a higher affinity for estrogen receptors [13, 28, 29]. We therefore investigated the expression of $\mathrm{ER} \alpha, \mathrm{ER} \beta$, and $\mathrm{AR}$ in $\mathrm{VCaP}$ cells after treatment with $1 \mu \mathrm{mol} / \mathrm{L} 3 \alpha$ - and

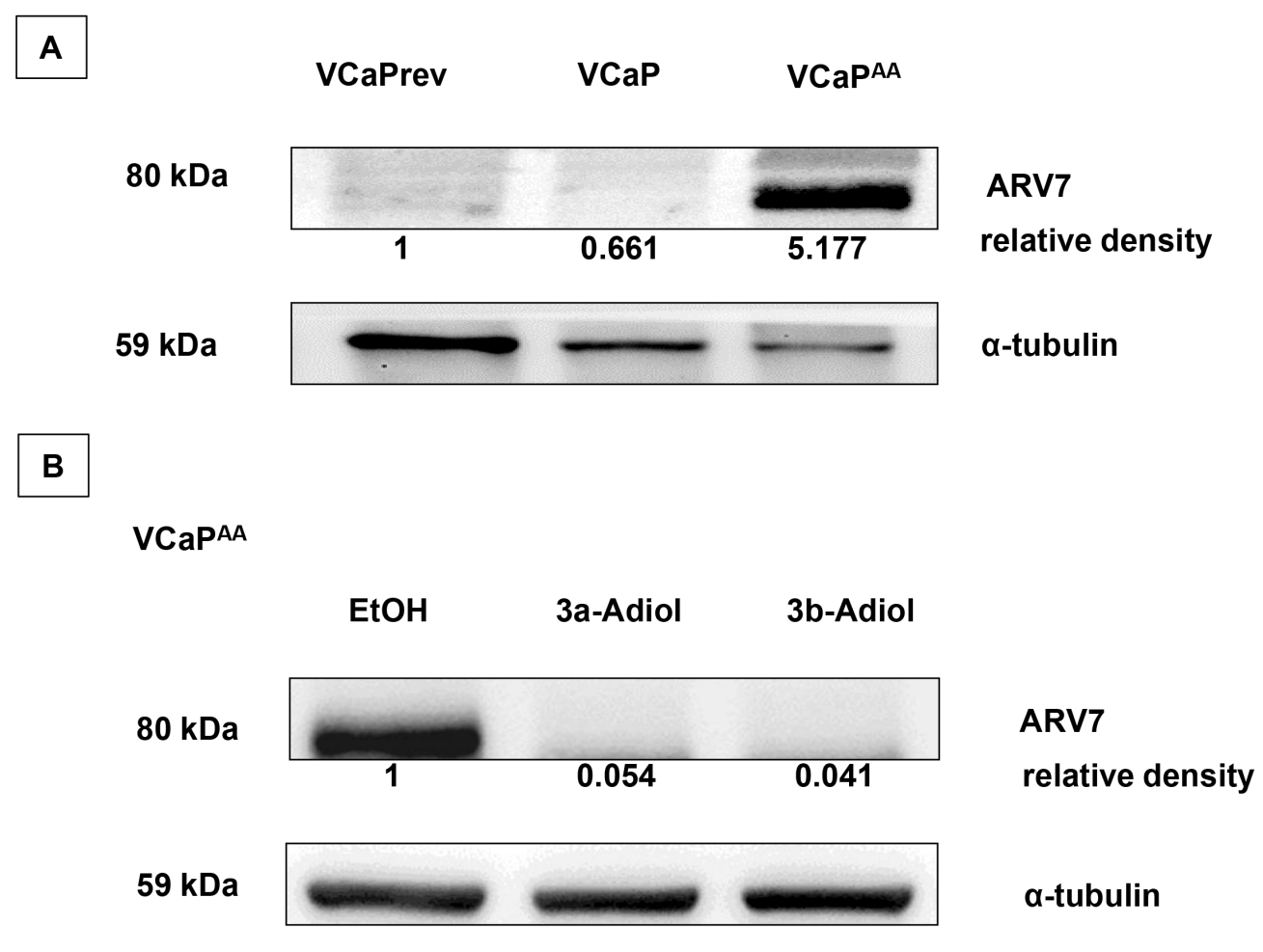

Figure 5: ARV7 expression in VCaP under increasing androgen deprivation. With increasing androgen deprivation therapy (ADT), the expression of full-length androgen receptor (flAR) continuously increased (as shown in Figure 4A-4C), which was accompanied by a stepwise increase in specific antibody staining for the AR splice variant 7 (ARV7), but only with maximum ADT (A). The strong ARV7 signal in the presence of abiraterone acetate was reversible upon additional treatments of VCaP AA cells with $1 \mu$ mol/L $3 \alpha$-adiol or $3 \beta$-adiol (B). 
$3 \beta$-adiol. Interestingly, this led to reduced AR expression, whereas ER $\alpha$ and ER $\beta$ were relatively unchanged. In addition, in gain-of-function AR-bearing $\mathrm{LNCaP}$ cells, AR expression was reduced after treatment with $1 \mu \mathrm{mol} / \mathrm{L} 3 \alpha$ and $3 \beta$-adiol. In these cells, the expression of ER $\alpha$ was also reduced, whereas ER $\beta$ protein expression was considerably increased. We hypothesized, according to our previous studies, that $3 \beta$-adiol binds/activates ER $\beta$, leading to downregulation of the AR [14]. Because the goal of CRPC therapy is to prevent activation of the AR, $3 \alpha$ - and $3 \beta$-adiol could be potential therapeutic options for CPRC treatment, without targeting the AR directly. Therefore, we conclude that these drugs have universal therapeutic potential, independent of CRPC characteristics and the promiscuous utilisation of steroids (Figures 4 and 5).

We further demonstrated that the decrease in proliferation after treatment with $3 \beta$-adiol or $3 \alpha$-adiol could be explained by a significant increase in tumour cell cycle arrest. This decrease is in agreement with results from Weihua et al. (2002), in which inhibition of growth in the developing ventral prostate was achieved with $3 \beta$-adiol [30].

Therapy resistance and cross resistance can be explained by constitutively active AR splice variants subverting further ADT by abiraterone, and by the loss of the specific targets for enzalutamide. The ER $\beta$-mediated anti-androgen effect has more universal potential, via the downregulation of such androgen-independent functions, and most importantly for gain-of-function mutations. This functional reciprocal counteraction of ER $\beta$ activation and AR suppression was most prominent for $3 \beta$-adiol in therapy-resistant ${ }_{\text {hiP }} \mathrm{LNCaP}^{\mathrm{AA}}$ cells (Figure $4 \mathrm{~F}$ ) but was also evident for other LNCaP models (Figure 4D, 4F). Counteraction of ER $\beta$ on ER $\alpha$ was also evident (Figure 4D-4F) [31, 32]. We recently investigated this reciprocal mechanism with the ER $\beta$ subtype-selective drug 8ßVE-2 [21]. Furthermore, we investigated the expression profile of AKRs with therapy resistance by investigating AR splice variants (Supplementary Figure 2). The occurrence of ARV7 appeared to re-introduce the profile of intact androgen signalling in an androgen-free environment (Figure 5). 3 $\beta$-adiol is synthesized from $5 \alpha$-DHT by AKR1C1, which is highly overexpressed with positive expression of ARV7 (Figure 5A and Supplementary Figure 2). This phenomenon might be explained by a feedback mechanism from complete AA-induced ADT and the established absence of DHT. However, this was reversed with experimental supplementation with $3 \beta$-adiol (Figure 5B).

In conclusion, our data suggest that the testosterone derivatives $3 \alpha$-adiol and $3 \beta$-adiol are able to inhibit tumour cell growth in several PCa cell lines and this decrease in proliferation could be explained by cell cycle arrest. ER $\alpha$ and $E R \beta$, as potential receptors of $3 \alpha$-adiol and $3 \beta$-adiol, seem to play an important role in PCa therapy resistance, potentially by influencing AR deregulation. Since these compounds evoked a decrease in AR expression, they could represent a potential therapeutic option, especially when therapy resistance by AR-aberrations occur in CRPC.

\section{MATERIALS AND METHODS}

\section{Culture of PCa cell lines}

We used the human prostate cancer cell lines $\mathrm{VCaP}$ (LGC Standards Teddington, England), and LNCaP, BPH-1 and PC-3 from local certified stocks as previously described [33, 34]. Briefly, for experiments cells were kept under 35 passages in phenol red-free Gibco ${ }^{\circledR}$ DMEM lot \# 1089200 (Life Technologies GmbH, Darmstadt, Germany) supplemented only with $2 \%$ sodium pyruvate and $10 \%$ fetal bovine serum, steroid-free according to the manufacturer's data sheet (PAA, Cölbe, Germany). To establish an androgen dependent variant $\mathrm{VCaP}$ cells were treated with $1 \mathrm{nmol} / \mathrm{L}$ testosterone (Sigma-Aldrich, Taufkirchen, Germany) over 20 passages yielding the androgen-sensitive cell line (VCAPrev) and for the generation of a therapy resistant cell line $\left(\mathrm{VCaP}^{\mathrm{AA}}\right) \mathrm{VCaP}$ cells were treated with $5 \mu \mathrm{mol} / \mathrm{L}$ AA (Janssen Cilag, Neuss, Germany) over 20 passages [21]. To demonstrate enduring resistance to prolonged androgen deprivation, also a high passage $(>100)$ variant from the gain-of-function AR cell line LNCaP was used $\left({ }_{\text {hip }} \mathrm{LNCaP}\right)$ [32], and was treated with $5 \mu \mathrm{mol} / \mathrm{L} \mathrm{AA}\left({ }_{\text {hip }} \mathrm{LNCaP}^{\mathrm{AA}}\right)$. Cells were incubated at $37^{\circ} \mathrm{C}$ and $5 \% \mathrm{CO}_{2}$ in a humidified incubator. Cells and supernatants were harvested for protein extraction or used for ELISA or FACS assays.

\section{Assessment of cell proliferation}

Tumour cell proliferation was evaluated by BrdUELISA. Cells were treated with $0.1,1$, or $10 \mathrm{nmol} / \mathrm{L}$ testosterone (article number: T6147, Sigma-Aldrich, Taufkirchen, Germany); 0.1, 1, 5, or $10 \mathrm{nmol} / \mathrm{L}$ DHT (article number: D5027, Sigma-Aldrich, Taufkirchen, Germany) and R1881 (article number: R0908, Sigma-Aldrich, Taufkirchen, Germany); and 0.01, 0.1, 1, 5, 10, 100, 250, or $1000 \mathrm{nmol} / \mathrm{L} 3 \alpha$-adiol and 3 $\beta$-adiol (article number: A1170000 for $3 \alpha$-adiol and A1220-000 for 3 $\beta$-adiol, both from Steraloids, Newport, Rhode Island, USA) for $48 \mathrm{~h}$.

\section{Western blotting}

Tumour cells were treated with $1 \mu \mathrm{mol} / \mathrm{L} 3 \alpha$-adiol, $1 \mu \mathrm{mol} / \mathrm{L}$ 3 $\beta$-adiol, $10 \mathrm{nmol} / \mathrm{L}$ R1881T, $10 \mathrm{nmol} / \mathrm{L}$ testosterone, or $10 \mathrm{nmol} / \mathrm{L}$ DHT. Total protein lysates were prepared using RIPA buffer with protease inhibitors (Roche, Germany). Concentrations were quantified by Bio-Rad DC Protein Assays (Bio-Rad, USA). Primary antibodies are listed in Table 1. Antibodies were detected by polyclonal rabbit anti-mouse immunoglobulins/HRP (1:1000, Dako, DK). Membranes were developed using ECL (Amersham Bioscience, Germany). 
Table 1: Antibodies used in this study

\begin{tabular}{|c|c|c|c|c|c|}
\hline Antibody & $\begin{array}{c}\text { Clone/article } \\
\text { number }\end{array}$ & host & Company & Solution & kDa \\
\hline androgen receptor (AR) & $\mathrm{Ab}-2$ & rabbit polyclonal & ThermoFisher & $1: 200$ & 110 \\
\hline $\begin{array}{l}\text { estrogen receptor } \\
\text { alpha }(\mathrm{ERa})\end{array}$ & MC-20 & rabbit polyclonal & Santa Cruz & $1: 1000$ & 66 \\
\hline $\begin{array}{l}\text { estrogen receptor } \\
\text { beta }(\operatorname{ER} \beta)\end{array}$ & 4D2 & mouse monoclonal & GeneTex & $1: 500$ & $58-60$ \\
\hline $\begin{array}{l}\text { aldo-keto reductase family } 1 \\
\text { member } \mathrm{C} 1 \text { (AKR1C1) }\end{array}$ & 859026 & mouse monoclonal & R\&D systems & $1: 1000$ & 37 \\
\hline $\begin{array}{l}\text { aldo-keto reductase family } 1 \\
\text { member C2 (AKR1C2) }\end{array}$ & 13035 & rabbit polyclonal & Cell signalling & $1: 1000$ & 37 \\
\hline $\begin{array}{l}\text { aldo-keto reductase family } 1 \\
\text { member C3 (AKR1C3) }\end{array}$ & 871701 & mouse monoclonal & R\&D systems & $1: 1000$ & 45 \\
\hline $\begin{array}{l}\text { androgen receptor splice } \\
\text { variant-7 (ARV7) }\end{array}$ & EPR15656 & rabbit monoclonal & abcam & $1: 1000$ & 80 \\
\hline$\alpha$-tubulin & $11 \mathrm{H} 10$ & rabbit monoclonal & Cell signalling & $1: 1000$ & 52 \\
\hline
\end{tabular}

\section{Assessment of cell cycle}

Cell cycle was evaluated after treatment with $1 \mu \mathrm{mol} / \mathrm{L} 3 \alpha$-adiol, $1 \mu \mathrm{mol} / \mathrm{L} 3 \beta$-adiol, or $10 \mathrm{nmol} / \mathrm{L}$ R1881 for $48 \mathrm{~h}$, using the Muse ${ }^{\mathrm{TM}}$ Cell Cycle assay as described by the manufacturer. Treated tumour cells $(200 \mu \mathrm{L})$ were centrifuged at $300 \times g$ for $5 \mathrm{~min}$ and washed with PBS; $200 \mu \mathrm{L}$ of ice-cold $70 \%$ ethanol was then added. Subsequently, cells were incubated for $3 \mathrm{~h}$ at $-20^{\circ} \mathrm{C}$ and $200 \mu \mathrm{L}$ of Muse ${ }^{\mathrm{TM}}$ Cell Cycle Reagent were added. Finally, tumour cells were incubated for $30 \mathrm{~min}$ at room temperature in the dark. Muse Cell Cycle Software Module was used for automatic calculations.

\section{Statistical analysis}

The mean $\pm \mathrm{SD}$ and $P$ values were evaluated with GraphPad Prism software version 5.0 using an unpaired non-parametric $t$ test and a $95 \%$ confidence interval (n.s. $=$ not significant, ${ }^{*} p<0.05,{ }^{* *} p<0.005$, and $\left.{ }^{* * *} p<0.0005\right)$.

\section{Author contributions}

F.B. and P.T. were responsible for the experimental design of the study, interpretation of the results and writing the manuscript. V.U. performed the experiments. H.J. was responsible for selection of the agents of steroid chemistry. H.J., S.K. and P.B. were supplied critical discussion of the experiments and results. HJ.R. and P.S. reviewed critically the manuscript.

\section{ACKNOWLEDGMENTS}

We thank Marion Striepe for perfect technical assistance.

\section{CONFLICTS OF INTEREST}

P.T. received consulting from Janssen-Cilag.

\section{FUNDING}

This work was supported by the Deutsche Forschungsgemeinschaft (to P.T.: TH 389/3-1, to P.B.: BU 992/6-1, to H.J.: JA 398/11-1, and to F.B.: BR 4700/1-1). We acknowledge support by the Open Access Publication Funds of the Göttingen University.

\section{REFERENCES}

1. Bray F, Lortet-Tieulent J, Ferlay J, Forman D, Auvinen A. Prostate cancer incidence and mortality trends in 37 European countries: an overview. Eur J Cancer. 2010; 46:3040-52. https://doi.org/10.1016/j.ejca.2010.09.013.

2. Center MM, Jemal A, Lortet-Tieulent J, Ward E, Ferlay J, Brawley $\mathrm{O}$, Bray F. International variation in prostate cancer incidence and mortality rates. Eur Urol. 2012; 61:1079-92. https://doi.org/10.1016/j.eururo.2012.02.054.

3. Heidenreich A, Bastian PJ, Bellmunt J, Bolla M, Joniau S, van der Kwast T, Mason M, Matveev V, Wiegel T, Zattoni F, Mottet N, and European Association of Urology. EAU guidelines on prostate cancer. Part II: treatment of advanced, relapsing, and castration-resistant prostate cancer. Eur Urol. 2014; 65:467-79. https://doi.org/10.1016/j. eururo.2013.11.002.

4. Scher HI, Beer TM, Higano CS, Anand A, Taplin ME, Efstathiou E, Rathkopf D, Shelkey J, Yu EY, Alumkal J, Hung D, Hirmand M, Seely L, et al, and Prostate Cancer Foundation/Department of Defense Prostate Cancer Clinical Trials Consortium. Antitumour activity of MDV3100 in castration-resistant prostate cancer: a phase 1-2 study. 
Lancet. 2010; 375:1437-46. https://doi.org/10.1016/ S0140-6736(10)60172-9.

5. Scher HI, Fizazi K, Saad F, Taplin ME, Sternberg CN, Miller $\mathrm{K}$, de Wit R, Mulders P, Chi KN, Shore ND, Armstrong AJ, Flaig TW, Fléchon A, et al, and AFFIRM Investigators. Increased survival with enzalutamide in prostate cancer after chemotherapy. N Engl J Med. 2012; 367:1187-97. https://doi. org/10.1056/NEJMoa1207506.

6. de Bono JS, Logothetis CJ, Molina A, Fizazi K, North S, Chu L, Chi KN, Jones RJ, Goodman OB Jr, Saad F, Staffurth $\mathrm{JN}$, Mainwaring P, Harland S, et al, and COU-AA-301 Investigators. Abiraterone and increased survival in metastatic prostate cancer. N Engl J Med. 2011; 364:19952005. https://doi.org/10.1056/NEJMoa1014618.

7. Ryan CJ, Smith MR, de Bono JS, Molina A, Logothetis CJ, de Souza P, Fizazi K, Mainwaring P, Piulats JM, Ng S, Carles J, Mulders PF, Basch E, et al, and COU-AA-302 Investigators. Abiraterone in metastatic prostate cancer without previous chemotherapy. N Engl J Med. 2013; 368:138-48. https://doi. org/10.1056/NEJMoa1209096.

8. Longo DL. New therapies for castration-resistant prostate cancer. N Engl J Med. 2010; 363:479-81. https://doi. org/10.1056/NEJMe1006300.

9. Knudsen KE, Penning TM. Partners in crime: deregulation of $\mathrm{AR}$ activity and androgen synthesis in prostate cancer. Trends Endocrinol Metab. 2010; 21:315-24. https://doi. org/10.1016/j.tem.2010.01.002.

10. Thelen P, Heinrich E, Bremmer F, Trojan L, Strauss A. Testosterone boosts for treatment of castration resistant prostate cancer: an experimental implementation of intermittent androgen deprivation. Prostate. 2013; 73:1699-709.

11. Stanbrough M, Bubley GJ, Ross K, Golub TR, Rubin MA, Penning TM, Febbo PG, Balk SP. Increased expression of genes converting adrenal androgens to testosterone in androgen-independent prostate cancer. Cancer Res. 2006; 66:2815-25. https://doi.org/10.1158/0008-5472. CAN-05-4000.

12. Baker ME. Recent insights into the origins of adrenal and sex steroid receptors. J Mol Endocrinol. 2002; 28:149-52. https:// doi.org/10.1677/jme.0.0280149.

13. Kuiper GG, Carlsson B, Grandien K, Enmark E, Häggblad J, Nilsson S, Gustafsson JA. Comparison of the ligand binding specificity and transcript tissue distribution of estrogen receptors alpha and beta. Endocrinology. 1997; 138:863-70. https://doi.org/10.1210/endo.138.3.4979.

14. Stettner M, Kaulfuss S, Burfeind P, Schweyer S, Strauss A, Ringert RH, Thelen $\mathrm{P}$. The relevance of estrogen receptorbeta expression to the antiproliferative effects observed with histone deacetylase inhibitors and phytoestrogens in prostate cancer treatment. Mol Cancer Ther. 2007; 6:2626-33. https:// doi.org/10.1158/1535-7163.MCT-07-0197.

15. Horvath LG, Henshall SM, Lee CS, Head DR, Quinn DI, Makela S, Delprado W, Golovsky D, Brenner PC, O’Neill
G, Kooner R, Stricker PD, Grygiel JJ, et al. Frequent loss of estrogen receptor-beta expression in prostate cancer. Cancer Res. 2001; 61:5331-35.

16. Latil A, Bièche I, Vidaud D, Lidereau R, Berthon P, Cussenot $\mathrm{O}$, Vidaud M. Evaluation of androgen, estrogen (ER alpha and ER beta), and progesterone receptor expression in human prostate cancer by real-time quantitative reverse transcription-polymerase chain reaction assays. Cancer Res. 2001; 61:1919-26.

17. Pasquali D, Rossi V, Esposito D, Abbondanza C, Puca GA, Bellastella A, Sinisi AA. Loss of estrogen receptor beta expression in malignant human prostate cells in primary cultures and in prostate cancer tissues. J Clin Endocrinol Metab. 2001; 86:2051-55.

18. Pasquali D, Staibano S, Prezioso D, Franco R, Esposito D, Notaro A, De Rosa G, Bellastella A, Sinisi AA. Estrogen receptor beta expression in human prostate tissue. Mol Cell Endocrinol. 2001; 178:47-50. https://doi.org/10.1016/ S0303-7207(01)00418-X.

19. Thelen P, Reupke V, Bremmer F, Jarry H. Early abiraterone treatment after surgical castration in in vivo castration resistant prostate cancer (CRPC) tumors in nude mice. J Clin Oncol. 2016 (Suppl 2); 34:263.

20. Antonarakis ES, Lu C, Wang H, Luber B, Nakazawa M, Roeser JC, Chen Y, Mohammad TA, Chen Y, Fedor HL, Lotan TL, Zheng Q, De Marzo AM, et al. AR-V7 and resistance to enzalutamide and abiraterone in prostate cancer. N Engl J Med. 2014; 371:1028-38. https://doi.org/10.1056/ NEJMoa1315815.

21. Gehrig J, Kaulfuß S, Jarry H, Bremmer F, Stettner M, Burfeind $\mathrm{P}$, Thelen $\mathrm{P}$. Prospects of estrogen receptor $\beta$ activation in the treatment of castration-resistant prostate cancer. Oncotarget. 2017; 8:34971-79. https://doi. org/10.18632/oncotarget.16496.

22. Urology EAo. (Update March 2015). Guidelines on Prostate Cancer. https://uroweb.org/guideline/prostate-cancer.

23. Attard G, Cooper CS, de Bono JS. Steroid hormone receptors in prostate cancer: a hard habit to break? Cancer Cell. 2009; 16:458-62. https://doi.org/10.1016/j.ccr.2009.11.006.

24. Chen Y, Sawyers CL, Scher HI. Targeting the androgen receptor pathway in prostate cancer. Curr Opin Pharmacol. 2008; 8:440-48. https://doi.org/10.1016/j.coph.2008.07.005.

25. Beer TM, Armstrong AJ, Rathkopf DE, Loriot Y, Sternberg $\mathrm{CN}$, Higano CS, Iversen $\mathrm{P}$, Bhattacharya $\mathrm{S}$, Carles J, Chowdhury S, Davis ID, de Bono JS, Evans CP, et al, and PREVAIL Investigators. Enzalutamide in metastatic prostate cancer before chemotherapy. N Engl J Med. 2014; 371:42433. https://doi.org/10.1056/NEJMoa1405095.

26. Schweizer MT, Antonarakis ES, Wang H, Ajiboye AS, Spitz A, Cao H, Luo J, Haffner MC, Yegnasubramanian S, Carducci MA, Eisenberger MA, Isaacs JT, Denmeade SR. Effect of bipolar androgen therapy for asymptomatic men with castration-resistant prostate cancer: results from a pilot 
clinical study. Sci Trans1 Med. 2015; 7:269ra2. https://doi. org/10.1126/scitranslmed.3010563.

27. Guerini V, Sau D, Scaccianoce E, Rusmini P, Ciana P, Maggi A, Martini PG, Katzenellenbogen BS, Martini L, Motta M, Poletti A. The androgen derivative 5alpha-androstane3beta,17beta-diol inhibits prostate cancer cell migration through activation of the estrogen receptor beta subtype. Cancer Res. 2005; 65:5445-53. https://doi.org/10.1158/00085472.CAN-04-1941.

28. Kuiper GG, Shughrue PJ, Merchenthaler I, Gustafsson JA. The estrogen receptor beta subtype: a novel mediator of estrogen action in neuroendocrine systems. Front Neuroendocrinol. 1998; 19:253-86. https://doi.org/10.1006/ frne.1998.0170.

29. Nilsson S, Mäkelä S, Treuter E, Tujague M, Thomsen J, Andersson G, Enmark E, Pettersson K, Warner M, Gustafsson JA. Mechanisms of estrogen action. Physiol Rev. 2001; 81:1535-65. https://doi.org/10.1152/physrev.2001.81.4.1535.

30. Weihua Z, Lathe R, Warner M, Gustafsson JA. An endocrine pathway in the prostate, ERbeta, AR, 5alpha-androstane-3beta,17beta-diol, and CYP7B1, regulates prostate growth. Proc Natl Acad Sci U S A. 2002; 99:1358994. https://doi.org/10.1073/pnas.162477299.

31. Gustafsson JA. ERbeta scientific visions translate to clinical uses. Climacteric. 2006; 9:156-160.

32. Warner M, Huang B, Gustafsson JA. Estrogen Receptor $\beta$ as a Pharmaceutical Target. Trends Pharmacol Sci. 2017; 38:92-99. https://doi.org/10.1016/j.tips.2016.10.006.

33. Fuessel S, Grobholz R, Krause H, Nawroth R, Thelen P, Schulz W, Unteregger G. Prostate cancer cell lines: identity stability and (cross) contamination. Urologe A. 2013; 52:132.

34. Bremmer F, Jarry H, Strauß A, Behnes CL, Trojan L, Thelen P. Increased expression of CYP17A1 indicates an effective targeting of the androgen receptor axis in castration resistant prostate cancer (CRPC). Springerplus. 2014; 3:574. https:// doi.org/10.1186/2193-1801-3-574. 